University of Nebraska - Lincoln

DigitalCommons@University of Nebraska - Lincoln

USGS Staff -- Published Research

US Geological Survey

2012

\title{
Strontium isotope systematics of mixing groundwater and oil-field brine at Goose Lake in northeastern Montana, USA
}

\author{
Zell E. Peterman \\ U.S. Geological Survey, pezell1001@msn.com \\ Joanna N. Thamke \\ U.S. Geological Survey, jothamke@usgs.gov \\ Kiyoto Futa \\ U.S. Geological Survey \\ Todd M. Preston \\ U.S. Geological Survey, tmpreston@usgs.gov
}

Follow this and additional works at: http://digitalcommons.unl.edu/usgsstaffpub

Part of the Geology Commons, Oceanography and Atmospheric Sciences and Meteorology Commons, Other Earth Sciences Commons, and the Other Environmental Sciences Commons

Peterman, Zell E.; Thamke, Joanna N.; Futa, Kiyoto; and Preston, Todd M., "Strontium isotope systematics of mixing groundwater and oil-field brine at Goose Lake in northeastern Montana, USA" (2012). USGS Staff -- Published Research. 934.

http://digitalcommons.unl.edu/usgsstaffpub/934

This Article is brought to you for free and open access by the US Geological Survey at DigitalCommons@University of Nebraska - Lincoln. It has been accepted for inclusion in USGS Staff -- Published Research by an authorized administrator of DigitalCommons@University of Nebraska - Lincoln. 


\title{
Strontium isotope systematics of mixing groundwater and oil-field brine at Goose Lake in northeastern Montana, USA
}

\author{
Zell E. Peterman ${ }^{\mathrm{a}, *}$, Joanna Thamke ${ }^{\mathrm{b}}$, Kiyoto Futa ${ }^{\mathrm{a}}$, Todd Preston ${ }^{\mathrm{c}}$ \\ ${ }^{a}$ U.S. Geological Survey, MS 963, Box 25046, DFC, Denver, CO 80225, United States \\ ${ }^{\mathrm{b}}$ U.S. Geological Survey, 3162 Bozeman Ave., Helena, MT 59601, United States \\ ' U.S. Geological Survey, 2327 University Way, Bozeman, MT 59715, United States
}

\section{A R T I C L E I N F O}

Article history:

Received 15 February 2012

Accepted 4 August 2012

Available online 24 August 2012

Editorial handling by R. Fuge

\begin{abstract}
A B S T R A C T
Groundwater, surface water, and soil in the Goose Lake oil field in northeastern Montana have been affected by $\mathrm{Cl}^{-}$-rich oil-field brines during long-term petroleum production. Ongoing multidisciplinary geochemical and geophysical studies have identified the degree and local extent of interaction between brine and groundwater. Fourteen samples representing groundwater, surface water, and brine were collected for $\mathrm{Sr}$ isotope analyses to evaluate the usefulness of ${ }^{87} \mathrm{Sr} /{ }^{86} \mathrm{Sr}$ in detecting small amounts of brine. Differences in $\mathrm{Sr}$ concentrations and ${ }^{87} \mathrm{Sr} /{ }^{86} \mathrm{Sr}$ are optimal at this site for the experiment. Strontium concentrations range from 0.13 to $36.9 \mathrm{mg} / \mathrm{L}$, and corresponding ${ }^{87} \mathrm{Sr} /{ }^{86} \mathrm{Sr}$ values range from 0.71097 to 0.70828 . The local brine has $168 \mathrm{mg} / \mathrm{L} \mathrm{Sr}$ and a ${ }^{87} \mathrm{Sr} /{ }^{86} \mathrm{Sr}$ value of 0.70802 . Mixing relationships are evident in the data set and illustrate the sensitivity of $\mathrm{Sr}$ in detecting small amounts of brine in groundwater. The location of data points on a $\mathrm{Sr}$ isotope-concentration plot is readily explained by an evaporation-mixing model. The model is supported by the variation in concentrations of most of the other solutes.
\end{abstract}

Published by Elsevier Ltd.

\section{Introduction}

The Prairie Pothole Region of the northern Great Plains of the USA and Canada (Fig. 1) contains many small lakes and sloughs in glacial till and outwash deposited at the margins of continental ice sheets during the Pleistocene. Sloan (1972) describes the water budget of these lakes as input by direct precipitation, basin runoff, and seepage inflow of groundwater and output by evapotranspiration, and seepage outflow. The groundwater and surface water is naturally saline with large concentrations of $\mathrm{Na}, \mathrm{Mg}, \mathrm{SO}_{4}^{2-}$ and $\mathrm{HCO}_{3}^{-}$and relatively small concentrations of $\mathrm{Cl}^{-}$. Salinity in some of the lakes increases seasonally because of evaporation during summer months. Others have reached an approximate equilibrium with groundwater recharge and evaporation and are perpetually saline. For example, Little Manitou Lake near Watrous, Saskatchewan, a highly saline lake with a density of 1.06 , has attracted visitors since the early 19th century because of the supposed curative powers of the water (Lewry, 2007). Other lakes in the region are of interest because they contain economic deposits of sodium sulfate or mirabolite (Kelley and Holmden, 2001). Further, the Prairie Pothole Region is a critical habitat for waterfowl and other terrestrial and aquatic species (Guntenspergen et al., 2006).

Many of the lakes have been drained for agricultural purposes, and many others have been affected by oil-field brines (Reiten

\footnotetext{
* Corresponding author. Tel.: +1 303236 7883; fax: +1 3032364930.

E-mail address: pezell1001@msn.com (Z.E. Peterman).
}

and Tischmak, 1993; Preston, 2011). Much of the Prairie Pothole Region is coincident with two major sedimentary basins that have produced oil and gas for more than $60 \mathrm{a}$ : (1) the Williston Basin centered in western North Dakota and extending into eastern Montana, southern Saskatchewan, and southwestern Manitoba (Fig. 1), and (2) the southern part of the Western Canada sedimentary basin in southern Alberta. The effects of releases and spills of highlysaline brines co-produced with oil during the past 60 a are widespread in Sheridan County, Montana (Reiten and Tischmak, 1993; Gleason et al., 2011; Preston, 2011). Reiten and Tischmak (1993) developed an index for identifying brine contamination (abbreviated here as CIx). This index is the ratio of $\mathrm{Cl}^{-}$concentration to specific conductance, both readily measured in the field. Oil-field brines are dominated by $\mathrm{Na}$ and $\mathrm{Cl}$ in halite proportions and may contain significant concentrations of other anions and cations including $\mathrm{B}, \mathrm{Ba}, \mathrm{Li}, \mathrm{Mn}, \mathrm{Sr}, \mathrm{Zn}, \mathrm{Br}$ and $\mathrm{I}$. More recent activity in the Williston Basin (Fig. 1) involves increased drilling and production from the Bakken Formation, a thin but widespread organicrich shale and sandstone unit that forms an extensive continuous petroleum system (Polastro et al., 2008).

The purpose of this study was to evaluate the use of Sr isotopes for detecting small amounts of oil-field brine in groundwater (Peterman et al., 2010). Previously, this approach has been used successfully to track the release of formation waters associated with production of $\mathrm{CH}_{4}$ from coal beds (Frost et al., 2002). Strontium is an alkaline-earth element that closely follows $\mathrm{Ca}$ in the hydrologic cycle. Combining the isotopic composition $\left({ }^{87} \mathrm{Sr} /{ }^{86} \mathrm{Sr}\right)$ 


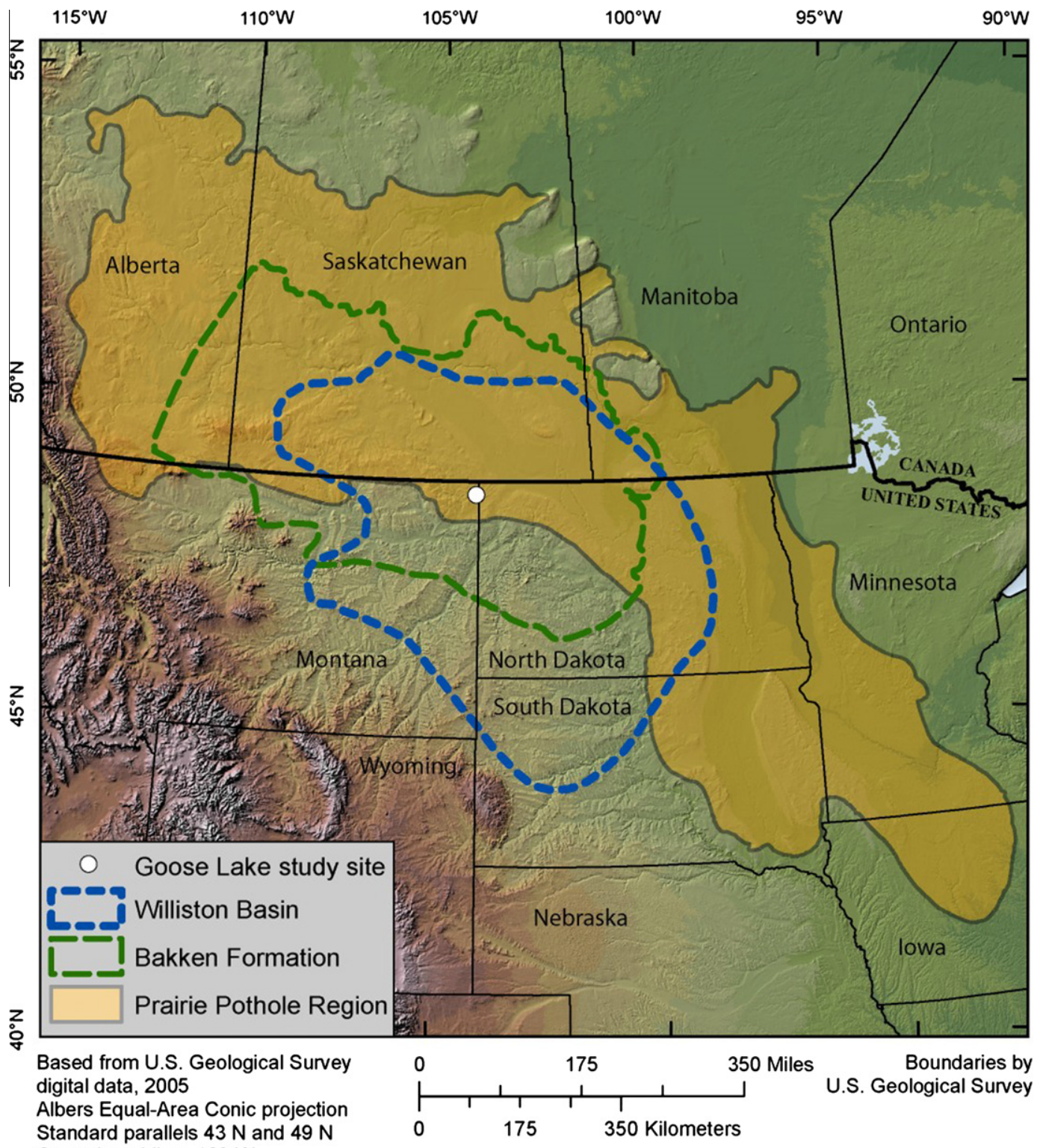

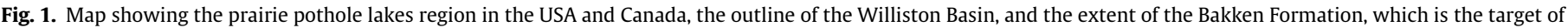
intense petroleum exploration and development. Location of the Goose Lake study area is shown by the white dot.

with the Sr concentration is an effective way to evaluate and quantify mixing, especially when the end members differ significantly in both isotope ratio and concentration (Peterman and Stuckless, 1992; Shand et al., 2009). An area within the Goose Lake oil field in northeastern Montana (Fig. 2) was selected to conduct this test because of an ongoing multidisciplinary study (http://steppe.cr.gov/), which has identified and delineated brine plumes (Reiten and Tischmak, 1993; Preston, 2011).

\section{Sample collection and analysis methods}

Water samples were collected from monitoring wells, wetlands, and an oil/brine separation tank at the Goose Lake study site during June 2009 (Table 1). Monitoring wells were purged until at least three well volumes of water were removed and onsite measurement of $\mathrm{pH}$, water temperature, and specific conductance had stabilized. Groundwater samples were collected using a $5 \mathrm{~cm}$ (2-in.) submersible pump.
Wetlands were sampled using a discrete sampling method modified from Knapton (1985). All of the wetland sites were shallow (typically less than $1.5 \mathrm{~m}$ deep) and tended to be well mixed by wind-generated turbulence, so a single sampling location was assumed to be representative of the entire wetland. Prior to sample collection, specific conductance was measured at various locations along the perimeter of the wetland to confirm adequate mixing. Samples were collected by wading to as deep a location as possible. An acid-rinsed 4-l polyethylene bottle was submersed upwind of the sample-collecting person and the lid was removed after submersion to fill the bottle. Brine samples were collected from a spigot located below the oil/brine separator tank. Each brine sample was collected in an acid-rinsed 4-l polyethylene bottle.

Quality-control data to document the reproducibility of analytical results and any sample contamination were provided by test samples that consisted of either a replicate sample or a fieldblank incorporated into the sample set. Quality-control samples comprised about $10 \%$ of the total number used for analyses. 


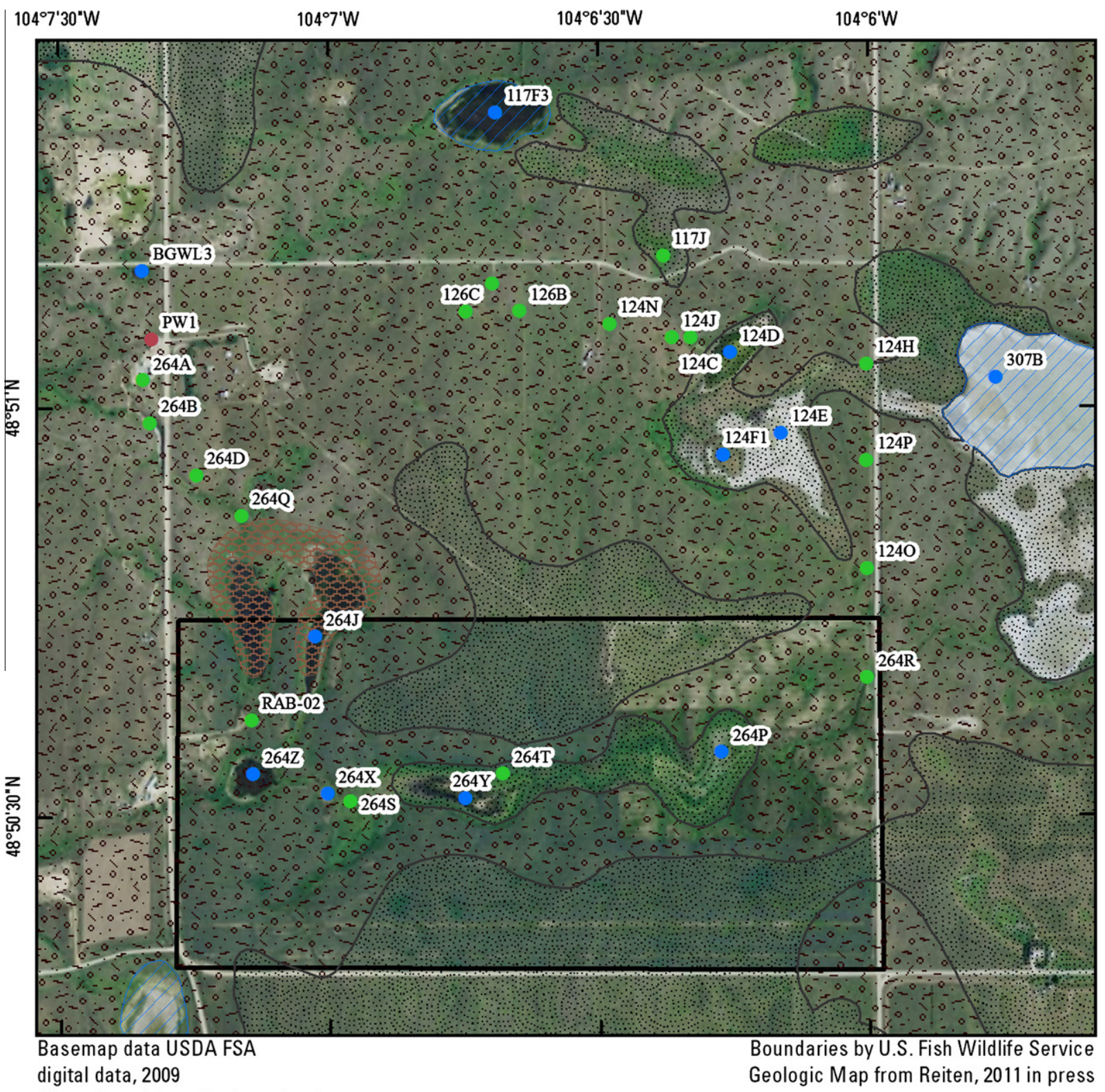

Albers Equal-Area Conic projection

Standard parallels $43 \mathrm{~N}$ and $49 \mathrm{~N}$

Central meridian - $103 \mathrm{~W}$

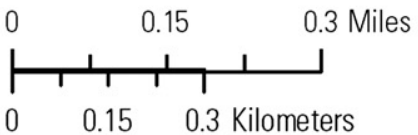

Water Quality Well Locations Surficial Geology
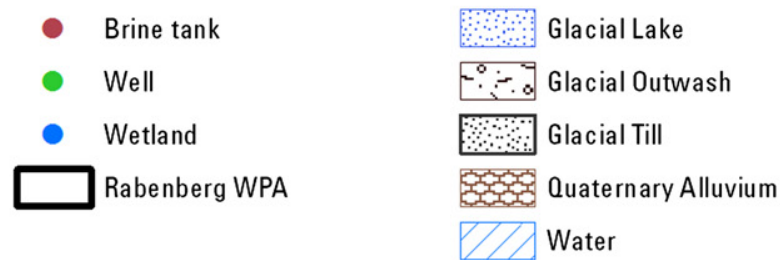

Fig. 2. Map of the Goose Lake study area showing sample locations and locations of oil wells.

Replicate samples were collected in the field by concurrently filling sample bottle sets.

Sample processing, filtration, and preservation were performed in the field using methods employed by the U.S. Geological Survey (variously dated). Samples of surface water and groundwater from shallow wells were collected in acid-washed polyethylene bottles following filtration to $0.45 \mu \mathrm{m}$.

In the laboratory, a sufficient volume of water to yield a few $\mu \mathrm{g}$ of $\mathrm{Sr}$ was evaporated to dryness in a Pyrex or Teflon beaker. The residue was dissolved in $3 \mathrm{~N} \mathrm{HNO}_{3}$ and passed through an Eichrom $\mathrm{Sr}$-spec resin in Teflon columns to isolate the $\mathrm{Sr}$ from other elements, particularly Rb. The Eichrom Sr-spec resin, cleaned by rinsing with many, equal-volumes of purified water over a period of time (about 1 month), had a column blank averaging $0.1 \mathrm{ng}$. The sample solution collected from the column was dried and dissolved with a drop of $1 \mathrm{~N} \mathrm{HCL}$, which was evaporated onto Re filaments and analyzed on an upgraded (Spectromat) Finnigan MAT $262^{\circledR}$, thermo-ionization mass spectrometer (TIMS). To eliminate 
Table 1

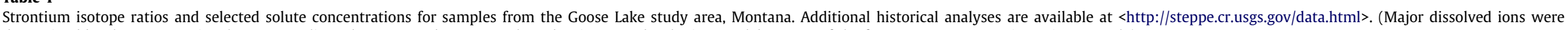
determined by the USGS National Water Quality Laboratory and trace metals and Sr isotopes, by the isotope laboratory of the former Yucca Mountain Project Branch.)

\begin{tabular}{|c|c|c|c|c|c|c|c|c|c|c|c|c|c|c|c|c|c|c|c|c|c|c|c|c|}
\hline $\begin{array}{l}\text { Site } \\
\text { name }\end{array}$ & $\begin{array}{l}\text { Latitude } \\
\text { NAD83 P }\end{array}$ & $\begin{array}{l}\text { Longitude } \\
\text { rojection }\end{array}$ & $\begin{array}{l}\text { Site } \\
\text { type }\end{array}$ & $\begin{array}{l}\text { Sample } \\
\text { date }\end{array}$ & $\begin{array}{l}\text { Field } \\
\mathrm{pH}\end{array}$ & $\begin{array}{l}\text { Specific } \\
\text { cond. } \\
(\mu \mathrm{S} / \mathrm{cm})\end{array}$ & $\begin{array}{l}\mathrm{Ca} \\
(\mathrm{mg} / \mathrm{L})\end{array}$ & $\begin{array}{l}\mathrm{Mg} \\
(\mathrm{mg} / \mathrm{L})\end{array}$ & $\begin{array}{l}\mathrm{K} \\
(\mathrm{mg} / \mathrm{L})\end{array}$ & $\begin{array}{l}\mathrm{Na} \\
(\mathrm{mg} / \mathrm{L})\end{array}$ & $\begin{array}{l}\text { Alkalinity } \\
\text { as CaCO }_{3} \\
(\mathrm{mg} / \mathrm{L})\end{array}$ & $\begin{array}{l}\mathrm{Br} \\
(\mathrm{mg} / \mathrm{L})\end{array}$ & $\begin{array}{l}\mathrm{Cl} \\
(\mathrm{mg} / \mathrm{L})\end{array}$ & $\begin{array}{l}\mathrm{F} \\
(\mathrm{mg} / \mathrm{L})\end{array}$ & $\begin{array}{l}\mathrm{SO}_{4} \\
(\mathrm{mg} / \mathrm{L})\end{array}$ & $\begin{array}{l}\mathrm{I} \\
(\mathrm{mg} / \mathrm{L})\end{array}$ & $\begin{array}{l}\mathrm{B} \\
(\mu \mathrm{g} / \mathrm{L})\end{array}$ & $\begin{array}{l}\mathrm{Ba} \\
(\mu \mathrm{g} / \mathrm{L})\end{array}$ & $\begin{array}{l}\mathrm{LI} \\
(\mu \mathrm{g} / \mathrm{L})\end{array}$ & $\begin{array}{l}\mathrm{Mn} \\
(\mu \mathrm{g} / \mathrm{L})\end{array}$ & $\begin{array}{l}\mathrm{Rb} \\
(\mu \mathrm{g} / \mathrm{L})\end{array}$ & $\begin{array}{l}\mathrm{Sr} \\
(\mu \mathrm{g} / \mathrm{L})\end{array}$ & $\begin{array}{l}\text { Contam. } \\
\text { Index }\end{array}$ & $\begin{array}{l}{ }^{87} \mathrm{Sr} /{ }^{86} \\
\mathrm{Sr} \\
\text { Atom } \\
\text { ratio }\end{array}$ \\
\hline $117 \mathrm{~F}$ & 48.8560 & -104.1115 & Wetland & 9/17/2009 & 9.07 & 10750 & 992 & 459 & 71.7 & 1044 & 84 & 4.05 & 2941 & 0.13 & 1775 & 0.034 & 1103 & 106 & 310 & 19 & 5.9 & 3970 & 0.27 & 0.71006 \\
\hline $117 \mathrm{~F}$ & 48 & - & Wetla & & 9.07 & 10690 & 967 & 4 & 69.4 & 10 & 8 & - & 2957 & 0.14 & & 0.034 & 1037 & 107 & 311 & 37 & 6.0 & 3980 & 0.28 & 0.71004 \\
\hline $124 \mathrm{D}$ & 48.8511 & -104.1042 & Well & 09 & 8.43 & 10600 & 284 & 1 & 6 & 1520 & 160 & 4.78 & 3280 & 0. & 605 & 0.2 & 7150 & 136 & 721 & 48 & 31.6 & 4320 & & 0.70858 \\
\hline $124 \mathrm{E}$ & 48.8495 & -104.1027 & Wetla & 09 & 8.93 & 00 & 306 & 2 & 97.9 & 3910 & & 12.5 & 7020 & 0.09 & & 0.449 & 14,200 & 149 & 1870 & 37 & 23.8 & 640 & 0.32 & 0.70861 \\
\hline $124 \mathrm{~F}$ & 48.8490 & 1045 & Wetlar & 09 & 8 & 0 & 3 & 1 & 54.5 & 21 & 256 & 5.98 & 4870 & 0.3 & ? & 0.107 & 7810 & 22 & 140 & 69 & 6.7 & 3170 & 0 & 0.70884 \\
\hline $124 \mathrm{~J}$ & 48.8514 & -104.1061 & Well & $4 / 2009$ & 7.37 & 17900 & 463 & 19 & 64.8 & 3060 & 257 & 10.7 & 6150 & 0.31 & 1 & 0.368 & 10,100 & 36 & 1400 & 1450 & 84.6 & 7610 & 0.34 & 0.70853 \\
\hline $126 \mathrm{C}$ & 48.8520 & -104.1124 & & & 7.23 & 3630 & 372 & 18 & 13.5 & 47.3 & 242 & 1.87 & 964 & 0. & & 0.039 & 64 & 185 & 121 & 2100 & 2 & 1590 & 0. & 0.70935 \\
\hline $264 \mathrm{~A}$ & 48.8506 & -104.1224 & Well & $3 / 2009$ & 6.92 & 91300 & 1370 & 543 & 402 & 18,600 & 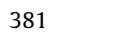 & 57.1 & 36,300 & 0.27 & 51 & 3.66 & 71,400 & - & 9340 & 6520 & 476 & 36,900 & 0.40 & 0.70828 \\
\hline 264J & 48.8453 & & & & 7.92 & & 345 & 419 & & & & & & 0. & & & 608 & 240 & 244 & 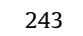 & 3.1 & 1300 & & 0.71097 \\
\hline $264 \mathrm{~K}$ & 48.8425 & -104.1190 & Wetland & $7 / 2009$ & 7.81 & 13980 & 648 & 51 & 65.6 & 1508 & 3 & 25 & 4738 & 0. & 41 & 0.075 & 1410 & 453 & 525 & 649 & 6.0 & 3340 & 0 & 0.71048 \\
\hline $264 \mathrm{M}$ & 48.8421 & & v & & 8.49 & & 110 & 128 & 30.2 & 551 & & & 1270 & 0. & 24 & $0 . c$ & 768 & 78 & 144 & 81 & 2.9 & 992 & 0 & 0.70991 \\
\hline $264 \mathrm{Y}$ & 48.8420 & -104.1125 & Wetland & $2 / 2009$ & 7.89 & 1080 & 8 & 52.1 & 19.9 & 45 & 19 & 0.06 & 120 & 0.05 & 181 & 0.015 & 199 & 74 & 40 & 17 & 2.7 & 431 & 0. & 0.71042 \\
\hline 307B & 48.8506 & -104.0961 & Wetland & & 8.83 & 66600 & 489 & 785 & 263 & 000 & & 30.6 & 4050 & 0.05 &, 300 & 0.291 & 5380 & 585 & 050 & 50 & 20 & 6360 & 0. & 0.70922 \\
\hline BGWL & 48.8528 & -104.1224 & Wetland & $5 / 15 / 2009$ & 8.43 & 387 & 43 & 8.04 & 16.7 & 22 & 190 & 0.02 & 9 & 0.05 & 0.83 & 0.015 & 258 & 35 & 9 & 2 & 1.7 & 130 & 0.02 & 0.70898 \\
\hline PW1 & 48.8514 & -104.1222 & Brine tank & $5 / 15 / 2009$ & - & 23000 & 5030 & 961 & 2040 & 0,500 & 142 & 240 & 121,000 & 2.65 & 1230 & 29.5 & 230,000 & 856 & 31,900 & 101 & 4370 & 16,800 & 0.54 & 0.70802 \\
\hline
\end{tabular}

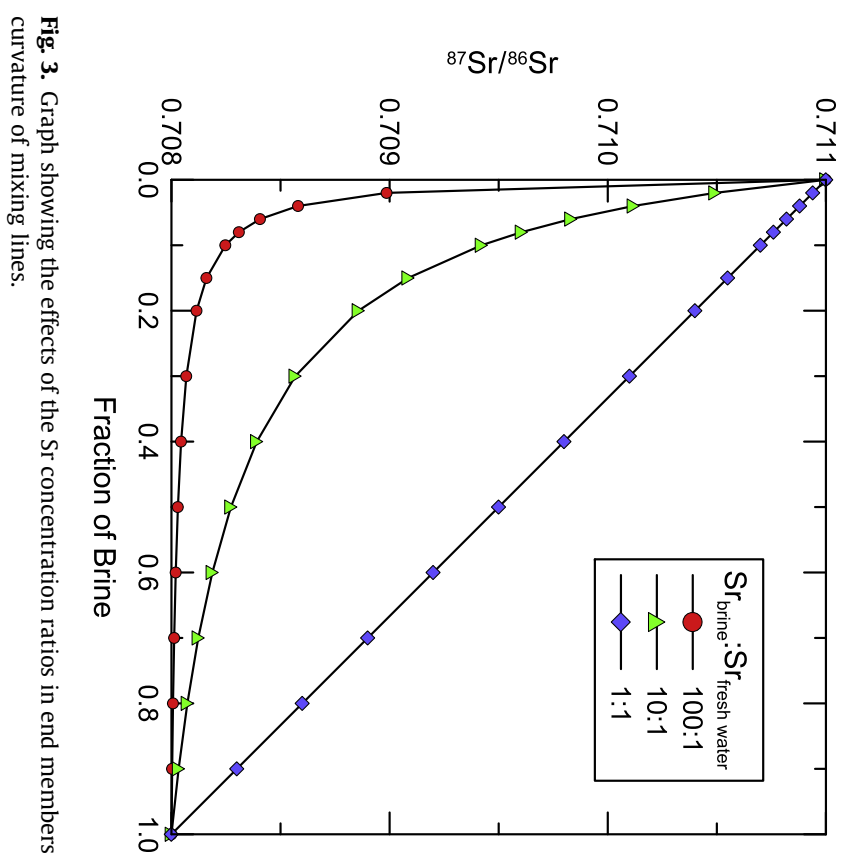

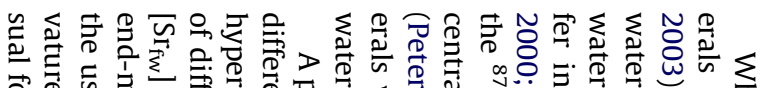

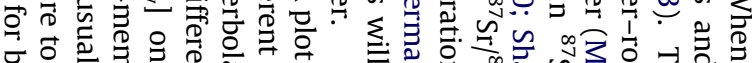

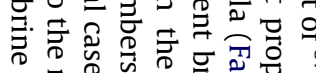
쿤.

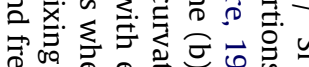

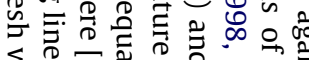

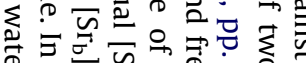
莺 E.

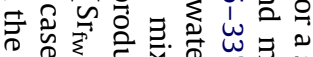

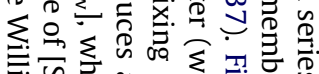

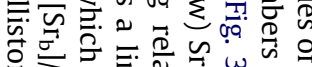

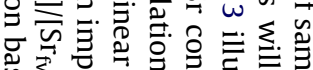
.

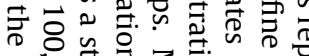

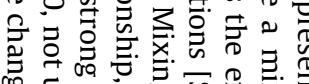

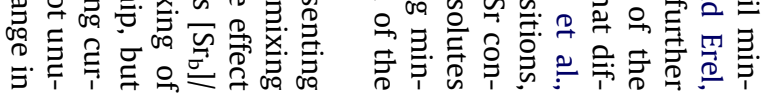

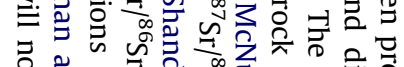

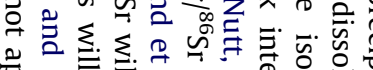

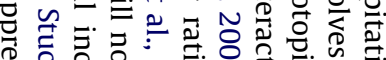

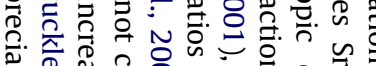

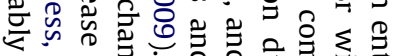

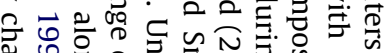

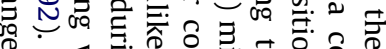

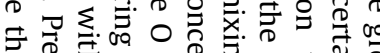

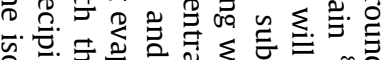

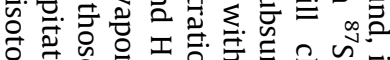

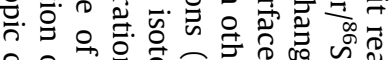

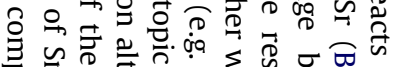

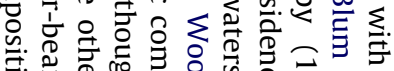

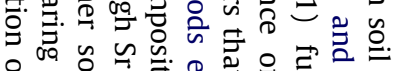

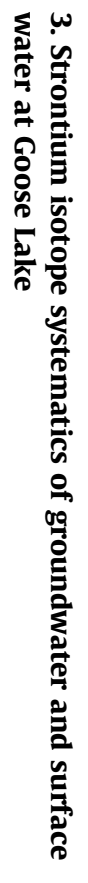

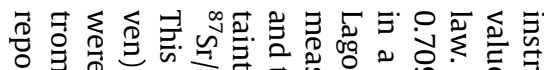

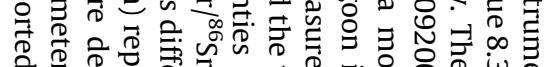

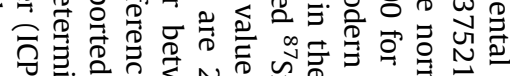

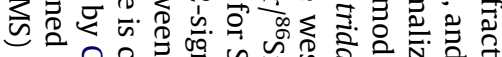

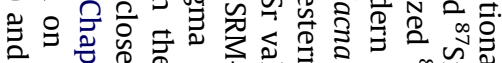

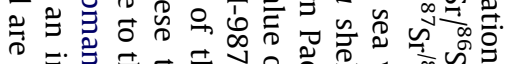

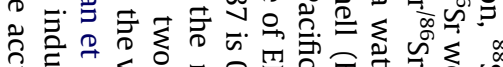

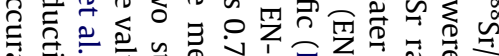

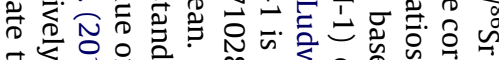

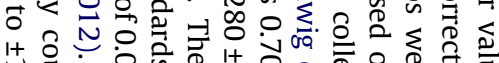

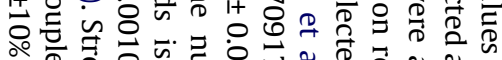

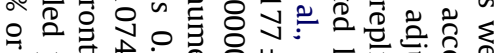

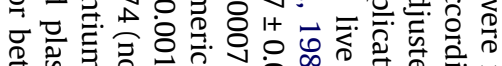

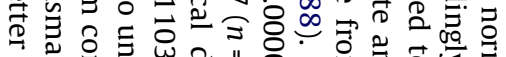

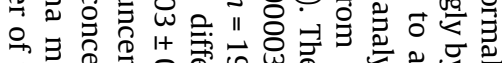

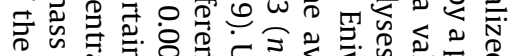

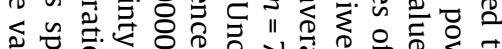

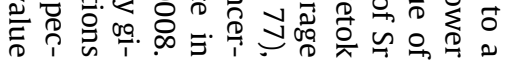


$\left({ }^{87} \mathrm{Sr} /{ }^{86} \mathrm{Sr}\right)_{\mathrm{b}}$ with a large dilution of fresh water has little effect on $\left({ }^{87} \mathrm{Sr} /{ }^{86} \mathrm{Sr}\right)_{\mathrm{M}}$, whereas a very small amount of brine contaminant in the fresh water component has a large effect on the $\left({ }^{87} \mathrm{Sr} /{ }^{86} \mathrm{Sr}\right)_{\mathrm{M}}$. This relationship illustrates the value of $\mathrm{Sr}$ isotopes in detecting small amounts of brine.

Differences in both $\mathrm{Sr}$ concentrations and ${ }^{87} \mathrm{Sr} /{ }^{86} \mathrm{Sr}$ are optimal at the Goose Lake site for conducting this experiment (Table 1). Strontium concentrations range from 0.13 to $36.9 \mathrm{mg} / \mathrm{L}$, and corresponding ${ }^{87} \mathrm{Sr} /{ }^{86} \mathrm{Sr}$ values range from 0.71097 to 0.70828 . Significant isotopic and concentration contrast is provided by the local brine with $168 \mathrm{mg} / \mathrm{L} \mathrm{Sr}$ and a ${ }^{87} \mathrm{Sr} /{ }^{86} \mathrm{Sr}$ value of 0.70802 . Strontium isotope ratios are plotted against widely ranging $\mathrm{Sr}$ concentrations (Table 1) on a semilog plot (Fig. 4) to illustrate an evaporation-mixing model for Goose Lake samples. The model is illustrated by the graphical inset (Fig. 4). Evaporation will increase solute concentrations, including [Sr] but will not change the ${ }^{87} \mathrm{Sr} /{ }^{86} \mathrm{Sr}$ values. Any water composition along the "evaporation" line can be influenced by brine, salts derived from brine evaporation, or by previously affected groundwater, and its composition will be drawn downward along a hyperbolic mixing line towards the brine composition. This process can occur in multiple stages and combinations of freshwater recharge, evaporation, and brine input, but the net results are shown by the data in Fig. 4 where a mixing zone is populated by samples representing the resultant isotopic and solute variability.

Three mixing lines connect PW1, the brine sample, with data points that bound the array and extend to the horizontal line of ${ }^{87} \mathrm{Sr} /{ }^{86} \mathrm{Sr}=0.71097$ (sample 264J). The distribution of data points in Fig. 4 indicates that in-mixing of brine will always lower the ${ }^{87} \mathrm{Sr} /{ }^{86} \mathrm{Sr}$ of water at the Goose Lake site. Thus, the value for $264 \mathrm{~J}$ is selected as the least modified ${ }^{87} \mathrm{Sr} /{ }^{86} \mathrm{Sr}$ value, and this ratio is used to calculate the mixing lines. In reality, there may well be samples with larger ${ }^{87} \mathrm{Sr} /{ }^{86} \mathrm{Sr}$ values indicating less brine involvement. There may also be significant ${ }^{87} \mathrm{Sr} /{ }^{86} \mathrm{Sr}$ variability in the unaffected groundwater reservoir. Neither of these possibilities detracts from the concept of the evaporation-mixing model. The two solid curves bound the data array with PW1-BGWL intersection at 0.71097 at $0.043 \mathrm{mg} / \mathrm{L} \mathrm{Sr}$, and PW1-264A at $4.138 \mathrm{mg} / \mathrm{L}$ Sr. The dashed mixing line is calculated through PW1 and 264Y to intersect the line at 0.71097 at $0.351 \mathrm{mg} / \mathrm{L}$ Sr. All but BGWL, a sample collected from a wetland containing recently-melted snow that is very low in solutes, are contained within the dashed curve and the solid curve passing through 0.71097 and $4.138 \mathrm{mg} / \mathrm{L} \mathrm{Sr}$.

The ${ }^{87} \mathrm{Sr} /{ }^{86} \mathrm{Sr}$ ratio of PW1 is similar to $\mathrm{Sr}$ isotope values for produced water from the Weyburn field in southern Saskatchewan (Quattrocchi et al., 2006) and to brines that affected groundwater in the Ft. Peck Indian Reservation in eastern Montana (Peterman et al., 2012). All of these brines were produced from the Mississippian Madison Group carbonate rocks. Data for the Weyburn brines are plotted in Fig. 4. The differences in $\mathrm{Sr}$ concentrations between that of PW1 and the lower values for the Weyburn samples may be the result of dilution of the latter during previous flooding of the reservoir with water from the Cretaceous Mannville aquifer with only a small effect on the ${ }^{87} \mathrm{Sr} /{ }^{86} \mathrm{Sr}$ values of the brine (Quattrocchi et al., 2006).

The sensitivity of $\mathrm{Sr}$ isotopes in detecting small amounts of brine can be estimated by considering sample 264Y. As mentioned above, the dashed mixing line passing through PW1 and 264Y with $0.431 \mathrm{mg} / \mathrm{L} \mathrm{Sr}$ intersects the horizontal line passing through 264J at $0.351 \mathrm{mg} / \mathrm{L} \mathrm{Sr}$. Only $0.05 \%$ brine (PW1) is required to move $264 \mathrm{Y}$ from the hypothetical original position at 0.351 and 0.71097 to its measured position in Fig. 4. Similarly, sample 264A could have been displaced from an original value on the 0.71097 line to the measured value of 0.70828 by only $20 \%$ brine.

The contamination index ( $\mathrm{Clx})$ is calculated for each sample in Table 1 using laboratory measurements of $\mathrm{Cl}^{-}$and specific conductance. CIx values for earlier sample collections from many of these sites are given by Reiten and Tischmak (1993). They considered CIx values of less than 0.035 to indicate uncontaminated water. One sample in Table 1, BGWL, has a CIx value lower than 0.035. In

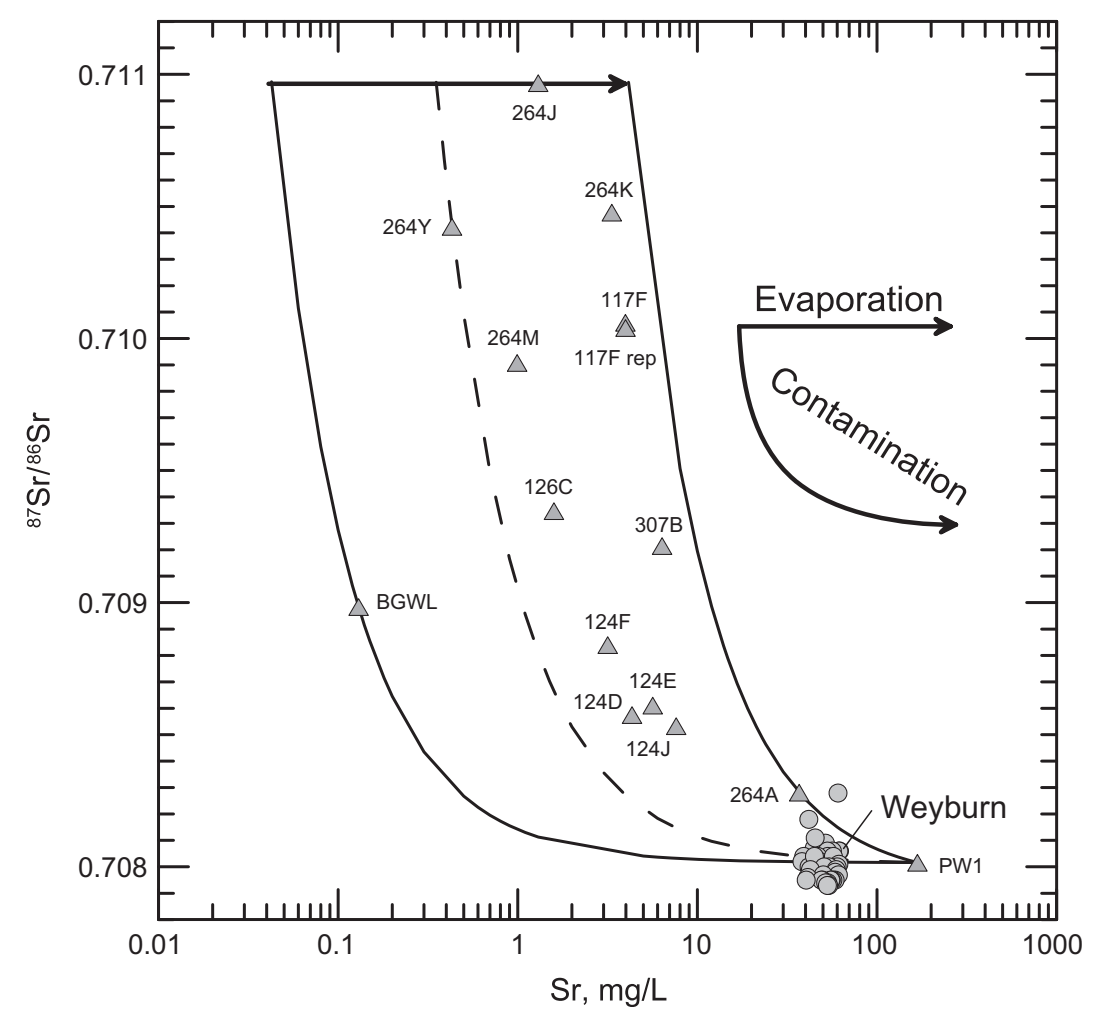

Fig. 4. Evaporation-mixing model for $\mathrm{Sr}$ isotope variation in surface and near-surface water at Goose Lake. 
the binary mixing model described above, only $0.005 \%$ PW1 would be required to move BGWL from its hypothetical original composition at $0.043 \mathrm{mg} / \mathrm{L} \mathrm{Sr}$ and a ${ }^{87} \mathrm{Sr} /{ }^{86} \mathrm{Sr}$ ratio of 0.71097 to its present position in Fig. 4. The relationship between $\mathrm{Clx}$ and the component of brine in other samples indicated by their location in Fig. 4 is complicated. The brine, PW1, has a CIx of 0.54, the largest value in the suite of samples. Sample 264Y, which has the largest component of brine based on the Sr model, has a CIx of 0.40. The cluster of samples 124D, E, F and J have similar CIx values of 0.31 to 0.34 . A marked departure from the general relationship is shown by 307B with a Clx of 0.06 . This sample is high in $\mathrm{SO}_{4}^{2-}$ and $\mathrm{Na}^{+}$resulting in a large specific conductance, but $\mathrm{Cl}^{-}$concentration is not especially enriched relative to many of the other samples.

Concentrations of other dissolved ions are also given in Table 1. Except for $\mathrm{HCO}_{3}^{-}$and $\mathrm{SO}_{4}^{2-}$, the relationships of these concentrations to ${ }^{87} \mathrm{Sr} /{ }^{86} \mathrm{Sr}$ values are generally consistent with the evaporation-mixing model. Neither $\mathrm{HCO}_{3}^{-}$nor $\mathrm{SO}_{4}^{2-}$ are necessarily conservative so departure from the model is not surprising.

\section{Conclusions}

As previous studies have shown, surface water and shallow groundwater at Goose Lake in northeastern Montana, have been variably affected by oil-field brines directly or through dissolution of salt deposits formed from the brines. Strontium concentrations in these waters and in oil-field brines differ by several orders of magnitude, and ${ }^{87} \mathrm{Sr} /{ }^{86} \mathrm{Sr}$ values are significantly different. An evaporation-mixing model is proposed. Seasonal evaporation increases solute concentrations but ${ }^{87} \mathrm{Sr} /{ }^{86} \mathrm{Sr}$ values of the water are not changed. An increasing brine component increases $\mathrm{Sr}$ and other solute concentrations and lowers the ${ }^{87} \mathrm{Sr} /{ }^{86} \mathrm{Sr}$ values. This mixing produces predictable relationships that can be used to detect very small amounts of brine.

\section{Acknowledgments}

The authors gratefully acknowledge helpful and constructive reviews by Craig Stricker (USGS), Carol Frost (University of Wyoming), David Gosselin (University of Nebraska), and two anonymous reviewers. Any use of trade, product, or firm names in this publication is for descriptive purposes only and does not imply endorsement by the U.S. Government.

\section{References}

Blum, J.D., Erel, Y., 2003. Radiogenic isotopes in weathering and hydrology. In: Drever, J.I. (Ed.), Surface and Ground Water, Weathering and Soils. Holland, H.D., Turekian, K.K. (Exec. Eds.), Treatise on Geochemistry, vol. 5. Elsevier, New York, pp. 365-392.

Chapman, E.C., Capo, R.C., Stewart, B.W., Kirby, C.S., Hammack, R.W., Schroeder, K.T. Edenborn, H.M., 2012. Geochemical and strontium isotope characterization of produced waters from Marcellus Shale natural gas extraction. Environ. Sci. Technol. 46, 3545-3553.
Faure, G., 1998. Principles and Applications of Geochemistry, second ed. Prentice Hall, Upper Saddle River, New Jersey.

Frost, C.D., Pearson, B.N., Ogle, K.M., Heffern, E.L., Lyman, R.M., 2002. Sr isotope tracing of aquifer interactions in an area of accelerating coal-bed methane production, Power River Basin, Wyoming. Geology 30, 923-926.

Gleason, R., Chesley-Preston, T., Preston, T., Smith, B., Tangen, B., Thamke, J., 2011. Examination of Brine Contamination Risk to Aquatic Resources from Petroleum Development in the Williston Basin. U.S. Geol. Surv. Fact Sheet 2011-3047.

Guntenspergen, G.R., Johnson, W.C., Naugle, D.E., 2006, Prairie Wetlands and Climate Change-Droughts and Ducks on the Prairies. U.S. Geol. Surv. Fact Sheet 2006-3144.

Kelley, L., Holmden, C., 2001. Reconnaissance hydrogeochemistry of economic deposits of sodium sulfate (mirabolite) in saline lakes, Saskatchewan, Canada. Hydrobiologia 466, 279-289.

Knapton, J., 1985. Field Guidelines for Collection, Treatment, and Analysis of Water Samples, Montana District: U.S. Geol. Surv. Open-File Report 85-409.

Lewry, M., 2007. Little Manitou Lake: University of Regina and Canadian Plaines Research Center. <http://esask.uregina.ca/entry/little_manitou_lake.html> (accessed 02.01.12).

Ludwig, K.R., Halley, R.B., Simmons, K.R., Peterman, Z.E., 1988. Strontium-isotope stratigraphy of Enewetak Atoll. Geology 16, 173-177.

McNutt, R.H., 2001. Strontium isotopes. In: Cook, P.G., Herczeg, A.L. (Eds.) Environmental Tracers, Subsurface Hydrology. Kluwer Academic Publishers, Boston/Dordrecht/London, pp. 233-260.

Peterman, Z.E., Stuckless, J.S., 1992. Application of strontium and other radiogenic tracer isotopes to paleohydrologic studies. In: Paleohydrological Methods and their Applications. Proc. NEA Workshop, Paris, November 9-10, 1992, pp. 5984.

Peterman, Z.E., Thamke, J., Futa, K., 2010. Use of Strontium Isotopes to Detect Produced Water Contamination in Surface Water and Groundwater in the Williston Basin, northeastern Montana. GeoCanada 2010, May 1014.

Peterman, Z.E., Thamke, J., Futa, K., Oliver, T.A., 2012. Strontium isotope evolution of produced water in the East Poplar Oil Field, Montana. American Association of Petroleum Geologists, Long Beach, California (Abstract).

Polastro, R.M., Cook, T.A., Roberts, L.N.R., Schenk, C.J., Lewan, M.D., Anna, L.O., Gaswirth S.B., Lillis, P.G., Klett, T.R., Charpentier, R.R., 2008. Assessment of Undiscovered oil Resources in the Devonian-Mississippian Bakken Formation, Williston Basin Province, Montana, and North Dakota, 2008. U.S. Geol. Surv. Fact Sheet 2008-3021.

Preston, T.M., 2011. Reexamining Saline Contamination Associated with Oil and Gas Development in the Prairie Pothole Region, Sheridan County, MT. MS Thesis Montana State Univ., Bozeman.

Quattrocchi, F., Barbieri, M., Bencini, R., Cinti, D., Durocher, K., Galli, G., Pizzino, L., Shevalier, M., Voltattorni, N., 2006. Strontium isotope $\left({ }^{87} \mathrm{Sr} /{ }^{86} \mathrm{Sr}\right)$ chemistry in produced oil field waters: The IEA $\mathrm{CO}_{2}$ monitoring and storage project. In: Lombardi, S., Altunina, L.K., Beaubien, S.E. (Eds.), Advances in the Geological Storage of Carbon Dioxide-International Approaches to Reduce Anthropogenic Greenhouse Gas Emissions. Proc. NATO Advance Research Workshop in $\mathrm{CO}_{2}$ Geological Sequestration in Eastern and Western European Countries, November 2004, Tomsk, Russia. Springer, The Netherlands, pp. 243-259.

Reiten, J.C., Tischmak, T., 1993. Appraisal of Oil Field Brine Contamination in Shallow Groundwater and Surface Water, eastern Sheridan County, Montana Montana Bur. Mines Geol., Open-File Report 260.

Shand, P., Darbyshire, D.P.F., Love, A.J., Edmunds, W.M., 2009. Sr isotopes in natural waters: applications to source characterization and water-rock interaction in contrasting landscapes. Appl. Geochem. 24, 574-583.

Sloan, C.E., 1972. Ground-water Hydrology of Prairie Potholes in North Dakota. U.S. Geol. Surv. Prof. Paper 585c, pp. C1-C28.

U.S. Geological Survey, variously dated. National Field Manual for the Collection of Water-Quality Data: U.S. Geological Survey Techniques of Water-Resources Investigations. <http://water.usgs.gov/owq/FieldManual/> (Book 9, Chapters A1-A9).

Woods, T.L., Fullagar, P.D., Spruill, R.K., Sutton, L.C., 2000. Strontium isotopes and major elements as tracers of ground water evolution: example from the upper Castle Hayne aquifer of North Carolina. Ground Water 38, 762-771. 